\title{
Hubungan Kadar IL-8 Sekret Mukosa Hidung pada Rinosinusitis Kronik tanpa Polip-Nonalergi dengan Fungsi Penghidu Setelah Pemberian Antibiotik Makrolid
}

\author{
Edo Wira Candra, ${ }^{1}$ Iwin Sumarman, ${ }^{2}$ Sinta Sari Ratunanda, ${ }^{2}$ Teti Madiadipoera ${ }^{2}$ \\ ${ }^{1}$ Rumah Sakit Petamedika Sentul City, ${ }^{2}$ Departemen Ilmu Kesehatan Telinga Hidung Tenggorok Bedah \\ Kepala Leher Fakultas Kedokteran Universitas Padjadjaran/Rumah Sakit Dr. Hasan Sadikin Bandung
}

\begin{abstract}
Abstrak
Rinosinusitis kronik (RSK) merupakan inflamasi kronik dengan etiologi multifaktorial. Interleukin-8 (IL-8) adalah sitokin proinflamasi yang dominan pada RSK tanpa polip-nonalergi. Penurunan fungsi penghidu merupakan suatu gejala yang sering dikeluhkan. Klaritromisin merupakan antibiotik makrolid yang efektif karena memiliki efek antibakteri dan antiinflamasi. Tujuan penelitian untuk mengetahui perbaikan gejala klinis, fungsi penghidu dan kadar IL-8 sekret mukosa hidung, serta mencari korelasi IL-8 dengan fungsi penghidu pada RSK tanpa polip-nonalergi. Penelitian ini merupakan randomized clinical trial open labeled pre and posttest design. Data dianalisis memakai Uji Wilcoxon, Mann Whitney, dan korelasi Rank Spearman. Penelitian berlangsung di poliklinik Ilmu Kesehatan Telinga Hidung Tenggorok Bedah Kepala Leher Rumah Sakit Dr. Hasan Sadikin pada 26 subjek yang dibagi menjadi dua kelompok. Kelompok pertama diberikan klaritromisin dan kelompok kedua diberikan amoksisilin-klavulanat. Diagnosis berdasarkan penilaian skor gejala dengan visual analogue scale (VAS), nasoendoskopi, fungsi penghidu dengan sniffin sticks test, dan dilakukan pengukuran kadar IL-8 sekret mukosa hidung dengan metode enzymelinked immunosorbent assay (ELISA). Didapatkan perbaikan VAS, nasoendoskopi, fungsi penghidu, dan kadar IL-8 yang signifikan $(\mathrm{p}=0,001)$ pada kedua kelompok pascaterapi, dan penurunan skor VAS total yang signifikan pada kelompok klaritromisin $(\mathrm{p}=0,036)$. Terdapat korelasi signifikan penurunan kadar IL-8 dengan peningkatan fungsi penghidu $(\mathrm{p}=0,05)$ dan dengan gejala hidung tersumbat $(\mathrm{p}=0,022)$ hanya pada kelompok klaritromisin. Simpulan, pemberian klaritromisin efektifmenurunkan gejala klinis terutama hidung tersumbat, meningkatkan fungsipenghidu, dan menurunkan kadar IL-8 sekret mukosa hidung pada RSK tanpa polip nonalergi. [MKB. 2014;46(1):6-14]
\end{abstract}

Kata kunci: Interleukin-8, klaritromisin, rinosinusitis kronik tanpa polip nonalergi, sniffin sticks test

\section{Correlation between IL-8 level of Nasal Secretion in Non Allergic- Chronic Rhinosunusitis without Nasal Polyp and Olfactory Function After Macrolide Treatment}

\begin{abstract}
Chronic rhinosinusitis (CRS) is a chronic inflammatory disease caused by multifactorial etiology. Interleukin- 8 (IL-8) plays an important role as a major proinflammatory cytokine in non-allergic chronic rhinosinusitis without polyp. The common symptom is olfactory function disturbance. Claritrhomycin as a macrolide antibiotics is effective for CRS because of their antibacterial and antiinflamatory activities. The purpose of this study was to observe improvement of clinical symptom depending on the visual analogue scale (VAS) score, olfactory function, IL-8 level of nasal secretion, and correlation between IL-8 with olfactory function in non-allergic CRS without nasal polyp. This was a randomized controlled trial open labeled pre- and post-test design. Data analysis used Wilcoxon, Mann Whitney, and rank Spearman correlation test. This study was conducted at the Otorhinolaryngology-Head and Neck Surgery Division of Dr. Hasan Sadikin General Hospital Bandung. There were 26 subjects divided in two groups, the first group was given clarithromycin and the second group was given amoxicillin-clavulanate. The two groups underwent visual analogue scale (VAS) assessment, nasoendoscopy, sniffing sticks test and nasal secretion of IL-8 by enzyme-linked immunosorbent assay (ELISA). The two groups had a significant improvement VAS score after therapy $(\mathrm{p}=0.001)$ and clarithromycin group showed a statistically significant $(\mathrm{p}=0.036)$ effect on decreasing the total VAS score compared to the amoxcicillin-clavulanate group. There was significant correlations between decreasing IL-8 level, increasing olfactory function $(\mathrm{p}=0.05)$, and nasal obstruction symptom in VAS ( $p=0.022$ ) was showed only in clarithromycin group. In conclusion, clarithromycin is effective in reducing clinical symptoms, especially in nasal obstruction, increasing olfactory function and decreasing IL-8 of nasal mucous secretion in non-allergic chronic rhinosinusitis without polyp. [MKB. 2014;46(1):6-14]
\end{abstract}

Key words: Clarithromycin, interleukin-8, non allergic-chronic rhinosinusitis without polyp, sniffin sticks test

Korespondensi: Edo Wira Candra, dr., M.Kes, Sp.THT-KL, Rumah Sakit Petamedika Sentul City, Jalan MH Thamrin No.1 Sentul City, Bogor, mobile 0817206061,e-mail dr.edo.chandra@gmail.com 


\section{Pendahuluan}

Rinosinusitis kronik (RSK) merupakan inflamasi mukosa hidung dan juga sinus paranasal dengan jangka waktu gejala $\geq 12$ minggu yang ditandai oleh $\geq 2$ gejala yang salah satunya berupa hidung tersumbat atau sekret nasal (anterior, posterior nasal drip). Keadaan ini dapat disertai nyeri wajah spontan atau pada penekanan, atau menurunnya sensasi penghidu serta hasil endoskopis berupa polip atau dapat juga sekret mukopurulen yang berasal dari meatus media dan atau edema/ obstruksi mukosa primer pada meatus media, dan/atau hasil dari computed tomography (CT) scan berupa perubahan mukosa pada kompleks osteomeatal dan atau sinus paranasal. ${ }^{1}$

Data dari Departemen Rinologi-Alergi Ilmu Kesehatan Telinga Hidung dan Tenggorok Bedah Kepala dan Leher (THT-KL) Rumah Sakit Dr. Hasan Sadikin Bandung (RSHS) pada tahun 2011 tercatat $46 \%$ kasus rinosinusitis, terdiri atas $46,04 \%$ laki-laki dan $53,86 \%$ pada perempuan. ${ }^{2}$ Rinosinusitis kronik merupakan penyakit yang sering ditemukan dengan insidensi dan prevalensi yang terus meningkat dan merupakan salah satu penyakit kronik paling sering di Amerika Serikat, yang secara kasar diperkirakan terjadi pada sekitar 35 juta penduduk Amerika setiap tahunnya. ${ }^{3}$

Rinosinusitis kronik merupakan penyakit yang dipengaruhi oleh multifaktorial ${ }^{1,4}$ dan menjadi penyebab utama gangguan penghidu. Sebanyak 61-83\% pasien RSK mengalami gangguan fungsi penghidu dan bahkan sekitar 25-30\% nya terdapat gangguan penghidu derajat sedang hingga berat. Gangguan fungsi penghidu ini secara signifikan menurunkan kualitas hidup. Penderita dengan gangguan penghidu acapkali memiliki kesulitan dalam berbagai hal seperti memasak, emosi yang tidak stabil, serta penurunan selera makan dan persepsi kebersihan diri. ${ }^{5}$

Penyebab gangguan fungsi penghidu pada rinosinusitis kronik berhubungan dengan faktor gangguan konduksi aliran udara dan gangguan sensorineural akibat kerusakan epitel olfaktori yang keduanya sering kali timbul bersamaan dengan derajat yang bervariasi. ${ }^{5}$ Dari suatu studi yang meneliti patologi mukosa hidung pada RSK didapatkan temuan antara lain perubahan struktural mukosa sel epitel olfaktorius normal pseudostratified bersilia dengan intermixing dari sel-sel goblet, metaplasia sel yang menyerupai sel skuamosa, dan terdapat gambaran erosi epitel olfaktorius. Selain itu, ditemukan juga penurunan jumlah persentase epitel normal dan juga neuron sensoris epitel olfaktori pada rinosinusitis kronik, terutama pada penderita dengan gangguan fungsi penghidu memperlihatkan gambaran erosi epitel dan konsentrasi tinggi infiltrasi sel antara lain eosinofil dan neutrofil pada mukosa. ${ }^{6}$

Di antara sitokin proinflamasi interleukin-8 (IL-8) didapatkan meningkat paling signifikan pada RSK nonalergi. Beberapa penulis sudah meneliti ekspresi dan sekresi IL-8 pada mukosa nasal dan paranasal pada orang normal serta yang mengalami inflamasi. Rekrutmen neutrofil dalam jumlah besar pada efusi sinus paranasal penderita rinosinusitis kronik bersifat signifikan. Interleukin-8 (IL-8) memicu aktivitas kemotaksis sel neutrofil yang poten. Interleukin-8 dihasilkan oleh beberapa sel, yaitu sel fibroblas, epitel, dan juga monosit darah perifer dan neutrofil. Sekresi IL-8 ini pada akhirnya akan menginduksi migrasi sel neutrofil lebih lanjut dan menjadikan suatu lingkaran purulensi lokal. ${ }^{7}$

Tujuan terapi RSK untuk mengurangi gejala dan tanda, mencegah perburukan atau rekurensi penyakit, dan juga meningkatkan kualitas hidup. ${ }^{8}$ Terapi medikamentosa maksimal harus dilakukan terlebih dahulu sebelum tindakan pembedahan.

Dalam suatu panduan tatalaksana rinosinusitis kronik dewasa, ${ }^{1}$ direkomendasikan penggunaan antibiotik, juga steroid topikal, serta pencucian hidung dengan larutan saline ( $\mathrm{NaCl}$ fisiologis). Pemilihan antibiotik sangatlah penting dengan memperhatikan berbagai jenis kemampuan, antara lain eradikasi bakteri, daya penetrasi ke mukosa dan sekret sinus, mampu meningkatkan gerakan silia, mencegah pembentukan biofilm bakteri, serta dapat memengaruhi sistem imun sehingga mampu menekan proses inflamasinya. ${ }^{9}$ Secara in vitro dari kultur sel epitel hidung manusia, pemberian makrolid dapat menghambat sekresi Interleukin-8 yang diinduksi oleh lipopolisakarida (LPS). Lipopolisakarida akan mengaktivasi sel monosit, yang akhirnya akan memproduksi IL-8 dan akan merangsang penarikan sel inflamasi ke tempat infeksi. Makrolid menekan IL-8 melalui activator protein-1 (AP-1) dan nuclear factor$\kappa B(\mathrm{NF}-\kappa \mathrm{B})$ pada sel epitel. Lipopolisakarida menstimulasi toll-like receptor-4 yang akan mengaktivasi AP-1 dan NF- $\kappa$ B, yang memainkan peranan utama dalam reaksi selular pada proses inflamasi. ${ }^{10}$

Dalam tatalaksana RSK, peranan antibiotik penting. Sesuai dengan panduan tatalaksana yang ada, ${ }^{1}$ amoksisilin-klavulanat menjadi salah satu terapi standar untuk RSK. Golongan penisilin telah luas dipergunakan untuk meminimalkan risiko resistensi golongan penisilin yang mampu eradikasi bakteri dengan betalaktamase yaitu dengan amoksisilin-klavulanat. Rechtweg dkk. ${ }^{11}$ menyatakan bahwa penderita yang mendapatkan terapi klaritromisin merasa lebih cepat membaik dibandingkan dengan penderita yang mendapat terapi amoksisilin-klavulanat pada hari ke-14, namun dalam keadaan kecepatan untuk eradikasi 
kuman patogen amoksisilin-klavulanat diketahui lebih cepat. Pada akhirnya setelah 28 hari, hasil kedua agen obat ternyata sama.

\section{Metode}

Penelitian ini merupakan randomized clinical trial open label pre and posttest design. Alokasi ke dalam perlakuan dilakukan secara randomisasi blok permutasi. Terhadap semua subjek penelitian dilaksanakan pemeriksaan gejala klinis dengan visual analogue scale (VAS), nasoendoskopi, penilaian skor fungsi penghidu dengan sniffin sticks test, dan pemeriksaan IL-8 sekret mukosa hidung dengan teknik nasal lavage.

Penelitian ini melibatkan sebanyak 26 subjek yang ditentukan berdasarkan taraf kepercayaan $95 \%$, power test $90 \%$, serta kemaknaan $\mathrm{p}<0,05$ yang terbagi menjadi dua kelompok penelitian, yaitu kelompok perlakuan sebanyak 14 subjek dan kontrol 12 subjek. Pada kelompok perlakuan terapi berupa antibiotik makrolid (klaritromisin) disertai kortikosteroid intranasal, sedangkan pada kontrol diberi antibiotik amoksisilin-klavulanat dan kortikosteroid intranasal. Pengamatan ulang dilakukan pada hari ke-14 pascaterapi.

Untuk analasis data penelitian ini digunakan Uji Wilcoxon, Mann Whitney, dan Korelasi Rank Spearman untuk mengetahui korelasi antara IL-8 dan variabel lainnya. Kemaknaan berdasarkan nilai $\mathrm{p}<0,05$.

Subjek penelitian adalah penderita RSK tanpa polip-nonalergi di poliklinik rinologi-alergi THTKL RSHS Bandung selama November-Desember 2012 yang sesuai dengan kriteria inklusi dan tidak termasuk kriteria eksklusi, serta menyetujui dan menandatangani lembar persetujuan (informed consent). Kriteria inklusi adalah penderita RSK tanpa polip nonalergiberdasarkan pada anamnesis, pemeriksaan fisis THT, nasoendoskopi, dan tes kulit tusuk dengan rentang usia 18 sampai 60 tahun, Kriteria eksklusi adalah RSK dengan polip hidung, terbukti positif alergi dengan skin prick test (SPT), riwayat asma, terdapat deviasi septum berat, alergi terhadap klaritromisin, amoksisilinklavulanat, pernah dilakukan pembedahan daerah hidung, dan terdapat riwayat laryngopharyngeal reflux (LPR).

\section{Hasil}

Terdapat 11 laki-laki dan 15 perempuan. Jenis kelamin kedua kelompok penelitian berdasarkan uji chi-kuadrat memiliki nilai $\mathrm{p}=0,126$ dan usia subjek penelitian berdasarkan Uji Mann Whitney memiliki nilai $\mathrm{p}=0,860$; maka dapat disimpulkan subjek pada kedua kelompok penelitian ini relatif homogen, sehingga layak untuk diperbandingkan (Tabel 1).

Dari hasil penelitian skor VAS, didapatkan perbaikan skor VAS pra dan pascaterapi dengan Uji Wilcoxon yang sangat bermakna meliputi keluhan rinore, hidung tersumbat, nyeri wajah dan gangguan penghidu baik pada kelompok perlakuan $(\mathrm{p}=0,001)$, sedangkan pada kelompok kontrol nilai $p=0,017$ hingga $p=0,002$ (Tabel 2). Berdasarkan perhitungan persentase penurunan skor VAS total rata-rata, VAS menurun sebanyak $62,2 \%$ pada kelompok klaritromisin dan $45 \%$ pada kelompok amoksisilin-klavulanat, sehingga didapatkan hasil yang berbeda signifikan melalui Uji Mann Whitney yaitu dengan nilai $Z_{\mathrm{M}-\mathrm{w}}=2,085$ dan $\mathrm{p}=0,036$.

Skor nasoendoskopi pada kedua kelompok terdapat perbedaan yang sangat bermakna (Uji Wilcoxon) pada pra dan pascaterapi yang meliputi perbaikan skor edema mukosa dengan nilai $\mathrm{p}=0,002$ pada kedua kelompok dan perbaikan

Tabel 1 Karakteristik Subjek Penelitian

\begin{tabular}{lccc}
\hline \multirow{2}{*}{ Karakteristik } & \multicolumn{2}{c}{ Kelompok Penelitian } & $\mathbf{p}$ \\
\cline { 2 - 3 } & Klaritromisin (n=14) & $\begin{array}{c}\text { Amoksisilin-klavulanat } \\
(\mathbf{n}=\mathbf{1 2})\end{array}$ & \multirow{2}{*}{0,126} \\
\hline Jenis kelamin & 4 & 7 & \\
$\quad$ Laki-laki & 10 & 5 & 0,860 \\
$\quad$ Perempuan & & & \\
Usia (tahun) & $38,5(13,7)$ & $37,9(11,8)$ & \\
$\quad$ Rata-rata (SD) & 37,50 & 34,00 & \\
Median & $18-60$ & $25-60$ & \\
Rentang & &
\end{tabular}

Keterangan: $\mathrm{SD}=$ standar deviasi; $\mathrm{n}=$ jumlah subjek penelitian; $\mathrm{p}<0,05=$ bermakna 
Tabel 2 Perbandingan Skor VAS

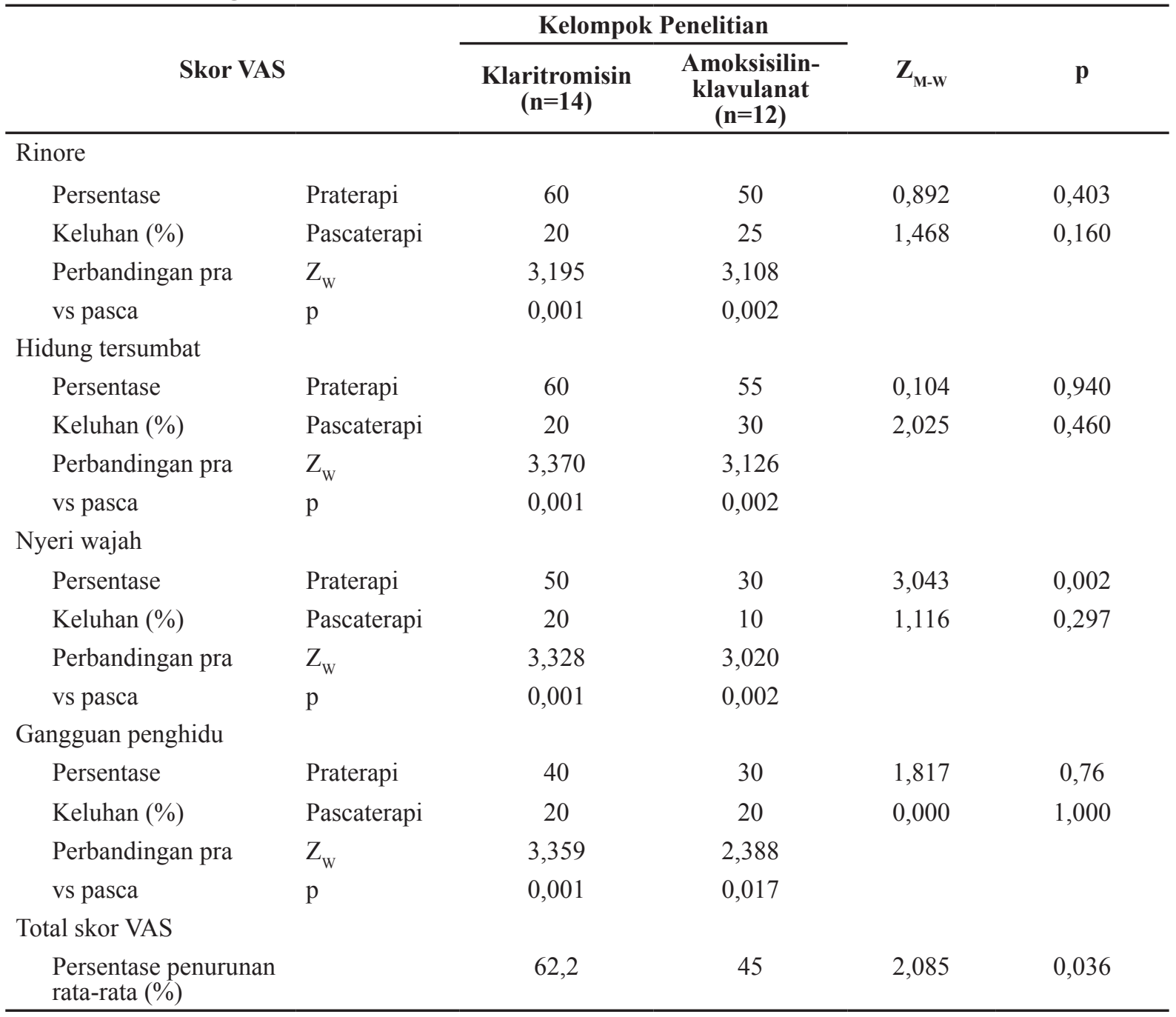

Keterangan: $\mathrm{Z}_{\mathrm{M}-\mathrm{W}}=\mathrm{Uji}$ Mann Whitney; $\mathrm{Z}_{\mathrm{w}}=\mathrm{Uji}$ Wilcoxon; $\mathrm{p}<0,05=$ bermakna

skor sekret hidung dengan nilai $\mathrm{p}=0,001$ pada kedua kelompok, namun Uji Mann Whitney untuk membandingkan kedua kelompok tidak memperlihatkan perbedaan bermakna pada skor edema pascaterapi $\left(Z_{M-\mathrm{w}}=0,952 ; \mathrm{p}=0,980\right)$ dan skor sekret $\left(Z_{M-W}=1,539 ; p=0,252\right.$; Tabel 3).

Berdasarkan pemeriksaan fungsi penghidu praterapi ternyata terdapat $7,7 \%$ pasien anosmia, $65,4 \%$ hiposmia, dan $23,1 \%$ normosmia. Pada pascaterapi didapatkan data $0 \%$ pasien anosmia, $46,15 \%$ hiposmia, dan $50 \%$ normosmia. Secara keseluruhan terjadi penurunan jumlah pasien anosmia dan hiposmia serta peningkatan jumlah pasien yang normosmia.

Terdapatperbedaan skorambang-diskriminasiidentifikasi (ADI) sniffin sticks test yang sangat bermakna pada pra dan pascaterapi dengan Uji Wilcoxon dengan nilai $\mathrm{p}=0,003$ pada kedua kelompok penelitian. Terdapat kecenderungan peningkatan persentase skor ADI rata-rata yang lebih baik pada kelompok perlakuan $(22,83 \%)$ dibandingkan dengan kelompok kontrol (14,08\%), namun secara statistik Uji Mann Whitney tidak didapatkan perbedaan yang bermakna antara kedua kelompok penelitian.

Terdapat penurunan kadar IL-8 yang sangat bermakna pra dibandingkan dengan pascaterapi (dengan Uji Wilcoxon) pada kedua kelompok penelitian dengan nilai $\mathrm{p}=0,001$ pada kelompok perlakuan dan $\mathrm{p}=0,002$ pada kontrol (Tabel 5). Persentase penurunan rata-rata dan perhitungan secara statistik menggunakan Uji Mann Whitney, penurunan IL-8 antara kelompok perlakuan dan kontrol tidak berbeda bermakna dengan nilai $\mathrm{Z}_{\mathrm{M}}$ $\mathrm{w}=0,051$ dan $\mathrm{p}=0,980$.

Untuk menentukan korelasi kadar IL-8 dan 
Edo Wira Candra: Hubungan Kadar IL-8 Sekret Mukosa Hidung pada Rinosinusitis Kronik tanpa Polip-Nonalergi

Tabel 3 Perbandingan Skor Nasoendoskopi

\begin{tabular}{|c|c|c|c|c|c|}
\hline \multirow{2}{*}{\multicolumn{2}{|c|}{ Nasoendoskopi }} & \multicolumn{2}{|c|}{ Kelompok Penelitian } & \multirow[b]{2}{*}{$\mathbf{Z}_{\mathrm{M}-\mathrm{W}}$} & \multirow[b]{2}{*}{$\mathbf{p}$} \\
\hline & & $\begin{array}{c}\text { Klaritromisin } \\
(\mathrm{n}=14)\end{array}$ & $\begin{array}{c}\text { Amoksisilin- } \\
\text { klavulanat } \\
(n=12)\end{array}$ & & \\
\hline \multicolumn{6}{|l|}{ Edema mukosa } \\
\hline \multirow[t]{2}{*}{ Praterapi } & Median & 2 & 2 & 0,669 & 0,631 \\
\hline & Rentang & $1-2$ & $1-2$ & & \\
\hline Pascaterapi & Median & 1 & 1 & 0,952 & 0,980 \\
\hline Perbandingan & Rentang & $0-1$ & $0-1$ & & \\
\hline \multirow[t]{2}{*}{ Pra vs Pasca } & $\mathrm{Z}_{\mathrm{w}}$ & 3,153 & 3,127 & & \\
\hline & $\mathrm{p}$ & 0,002 & 0,002 & & \\
\hline Sekret hidung & Median & 2 & 1,50 & 1,497 & 0,231 \\
\hline \multirow[t]{2}{*}{ Praterapi } & Rentang & $1-2$ & $1-2$ & & \\
\hline & Median & 0,00 & 0,00 & 1,539 & 0,252 \\
\hline Pascaterapi & Rentang & $0-1$ & $0-1$ & & \\
\hline Perbandingan & $\mathrm{Z}_{\mathrm{w}}$ & 3,416 & 3,357 & & \\
\hline Pra vs Pasca & $\mathrm{p}$ & 0,001 & 0,001 & & \\
\hline
\end{tabular}

Keterangan: $\mathrm{Z}_{\mathrm{M}-\mathrm{w}}=$ Uji Mann Whitney; $\mathrm{Z}_{\mathrm{W}}=$ Uji Wilcoxon; $\mathrm{p}<0,05=$ bermakna

variabel lainnya dipergunakan Uji Korelasi Rank Spearman (Tabel 6). Koefisien korelasi ditetapkan sebesar $r>0,4$. Berdasarkan perhitungan secara statistik, terlihat korelasi yang bermakna antara penurunan kadar IL-8 dan penurunan skor VAS hidung tersumbat kelompok perlakuan $(r=0,605$; $\mathrm{p}=0,022$; Tabel 6). Dapat juga dilihat korelasi antara IL-8 dan skor penghidu (ADI) bila dilakukan uji satu pihak dengan nilai $\mathrm{p}=0,05$.

\section{Pembahasan}

Menurut panduan European Position Paper

Tabel 4 Perbandingan Skor Fungsi Penghidu (ADI)

\begin{tabular}{|c|c|c|c|c|c|}
\hline \multirow{2}{*}{ Skor ADI } & & \multicolumn{2}{|c|}{ Kelompok Penelitian } & \multirow[b]{2}{*}{$\mathrm{Z}_{\mathrm{M}-\mathrm{W}}$} & \multirow[b]{2}{*}{$\mathbf{p}$} \\
\hline & & $\begin{array}{c}\text { Klaritromisin } \\
(n=14)\end{array}$ & $\begin{array}{c}\text { Amoksisilin- } \\
\text { klavulanat }(n=12)\end{array}$ & & \\
\hline \multicolumn{6}{|l|}{ Praterapi } \\
\hline $\mathrm{X}(\mathrm{SD})$ & & $24,12(7,16)$ & $25,69(5,21)$ & 0,438 & \\
\hline Median & & 25,88 & 26,50 & & \\
\hline Rentang & & $11,38-33,88$ & $15,88-33,0$ & & \\
\hline \multicolumn{6}{|l|}{ Pascaterapi } \\
\hline $\mathrm{X}(\mathrm{SD})$ & & $28,45(5,72)$ & $29,0(5,17)$ & 0,466 & 0,647 \\
\hline Median & & 29,50 & 31,5 & & \\
\hline Rentang & & $18,0-37,38$ & $19,75-33,5$ & & \\
\hline Perbandingan pra & $\mathrm{Z}_{\mathrm{w}}$ & 3,014 & 2,973 & & \\
\hline vs pasca & $\mathrm{p}$ & 0,003 & 0,003 & & \\
\hline$\%$ Peningkatan (ra & & 22,83 & 14,08 & 1,095 & 0,291 \\
\hline
\end{tabular}

Keterangan: $\mathrm{ADI}=$ ambang-diskriminasi-identifikasi (sniffin sticks test), $\mathrm{Z}_{\mathrm{M}-\mathrm{W}}=\mathrm{Uji}$ Mann Whitney; $\mathrm{Z}_{\mathrm{W}}=\mathrm{Uji}$ Wilcoxon; $\mathrm{p}<0,05=$ bermakna 
Tabel 5 Perbandingan Kadar IL-8

\begin{tabular}{|c|c|c|c|c|c|}
\hline \multirow{2}{*}{ IL-8 } & & \multicolumn{2}{|c|}{ Kelompok Penelitian } & \multirow[b]{2}{*}{$\mathbf{Z}_{\mathrm{M}-\mathrm{W}}$} & \multirow[b]{2}{*}{$\mathbf{p}$} \\
\hline & & $\begin{array}{c}\text { Klaritromisin } \\
(n=14)\end{array}$ & $\begin{array}{c}\text { Amoksisilin- } \\
\text { klavulanat }(n=12)\end{array}$ & & \\
\hline \multicolumn{6}{|l|}{ Praterapi } \\
\hline $\mathrm{X}(\mathrm{SD})$ & & $225,51(486,6)$ & $50,31(70,08)$ & 1,106 & 0,274 \\
\hline Median & & 51,01 & 28,48 & & \\
\hline Rentang & & $11,89-1616$ & $11,89-266,40$ & & \\
\hline \multicolumn{6}{|l|}{ Pascaterapi } \\
\hline $\mathrm{X}(\mathrm{SD})$ & & $70,53(192,63)$ & $16,60(8,73)$ & 0,515 & 0,631 \\
\hline Median & & 17,58 & 13,38 & & \\
\hline Rentang & & $9,41-738,90$ & $9,90-40,11$ & & \\
\hline Perbandingan pra & $\mathrm{Z}_{\mathrm{w}}$ & 3,296 & 3,059 & & \\
\hline vs pasca & $\mathrm{p}$ & 0,001 & 0,002 & & \\
\hline$\%$ Peningkatan $(1$ & & 47,7 & 45,2 & 0,051 & 0,980 \\
\hline
\end{tabular}

Keterangan: IL-8=interleukin-8; $\mathrm{Z}_{\mathrm{M}-\mathrm{W}}=$ Uji Mann Whitney; $\mathrm{Z}_{\mathrm{W}}=$ Uji Wilcoxon; $\mathrm{p}<0,05=$ bermakna

on Rhinosinusitis and Nasal Polyps (EP3OS) 2012, ${ }^{1}$ prevalensi RSK ditemukan lebih tinggi pada wanita bila dibandingkan dengan pria (rasio 6:4) dengan rentang prevalensi sekitar 3,4\% pada pria dan $5,7 \%$ pada wanita. Berdasarkan literatur lainnya perbandingan prevalensi lakilaki $45,33 \%$ dan perempuan $54,67 \%$ dengan hasil tidak terdapat perbedaan yang bermakna antara gender. ${ }^{12}$ Pada penelitian ini ditemukan prevalensi RSK tanpa polip nonalergi perempuan dan laki-laki dengan perbandingan 1,4:1 hampir mendekati perbandingan prevalensi secara umum. Persentase prevalensi didapatkan yaitu laki-laki 42,3\% dan perempuan $57,7 \%$ dan secara statistik tidak didapatkan perbedaan yang signifikan antar gender.
Terdapat penurunan skor VAS yang bermakna pada keluhan rinore, hidung tersumbat, nyeri wajah, dan juga gangguan penghidu antara kedua kelompok perlakuan. Tidak didapat perbedaan yang bermakna pada skor VAS tanda klinis antara kelompok perlakuan dan kontrol pascaterapi. Didapatkan hasil yang berbeda bermakna $\left(\mathrm{Z}_{\mathrm{M}}\right.$ $=2,085 ; \mathrm{p}=0,036)$ berdasarkan pada Uji Mann Whitney bila ditilik persentase penurunan skor total VAS, diketahui bahwa penurunan skor total VAS pada kelompok klaritromisin $62,2 \%$ lebih baik bila dibandingkan dengan kelompok amoksisilin-klavulanat dengan penurunannya hanya $45 \%$. Sarafraz dkk. ${ }^{13}$ yang menggunakan klaritromisin $2 \times 500 \mathrm{mg}$ sehari selama tiga bulan, $66,6 \%$ di antaranya memberikan hasil yang baik

Tabel 6 Korelasi Kadar IL-8 dengan Variabel lainnya

\begin{tabular}{lcccc}
\hline \multirow{2}{*}{ Korelasi IL-8 } & \multicolumn{2}{c}{ Kelompok Klaritromisin } & \multicolumn{2}{c}{ Kelompok Amoksisilin-klavulanat } \\
\cline { 2 - 5 } & $\mathbf{r}_{\mathrm{s}}$ & $\mathbf{p}$ & $\mathbf{r}_{\mathrm{s}}$ & $\mathbf{p}$ \\
\hline Skor nasoendoskopi & 0,115 & 0,695 & 0,288 & 0,158 \\
VAS rinore & 0,151 & 0,606 & 0,068 & 0,833 \\
VAS hidung tersumbat & 0,605 & 0,022 & 0,283 & 0,372 \\
VAS nyeri wajah & 0,056 & 0,848 & 0,483 & 0,112 \\
VAS gangguan penghidu & 0,154 & 0,598 & 0,139 & 0,666 \\
Skor total VAS & 0,308 & 0,284 & 0,050 & 0,878 \\
Skor penghidu (ADI)* & 0,458 & 0,100 & 0,136 & 0,689 \\
\hline
\end{tabular}

Keterangan: IL-8=interleukin-8; VAS=visual analogue scale; $\mathrm{ADI}=$ ambang-diskriminasi-identifikasi rs=koefisien korelasi Rank Spearman; rs $>0,4=$ bermakna; *) uji dua pihak 
terhadap pengobatan meliputi perbaikan skor endoskopi hidung dan VAS yang paling signifikan berubah adalah keluhan hidung tersumbat dengan $\mathrm{p}<0,05$ dan secara umum didapatkan perbaikan gejala, namun tidak didapatkan perubahan yang signifikan pada penghidu.

Kombinasiklaritromisin dengan kortikosteroid topikal intranasal mampu memperbaiki fungsi penghidu penderita rinosinusitis kronik, karena efektivitas kortikosteroid topikal intranasal yang baik pada pengobatan rinosinusitis dan juga dapat memperbaiki patensi kompleks osteomeatal ini dengan mengurangi inflamasi mukosa. Kombinasi dengan antibiotik golongan makrolid didapatkan peningkatan efektivitas derajat sedang dalam mengurangi gejala klinis. Kelebihan klaritromisin antara lain mampu meningkatkan sensitivitas reseptor steroid, sehingga dapat meningkatkan efek terapi. ${ }^{8}$ Hal ini sesuai dengan hasil penelitian pada kelompok perlakuan yang menggunakan kombinasi klaritromisin dengan kortikosteroid topikal intranasal dengan efektivitas yang tinggi terhadap perbaikan klinis bukan hanya pada perbaikan fungsi penghidu namun terutama keluhan hidung tersumbat, rinore, dan juga nyeri wajah pun mengalami perbaikan yang signifikan pascaterapi melalui Uji Wilcoxon dengan nilai $p=0,001$. Temuan ini berbeda dengan penelitian sebelumnya yang telah dilakukan oleh Moretti dkk. ${ }^{14}$ dengan kortikosteroid intranasal tunggal dan penelitian yang dilakukan Sarafraz dkk. ${ }^{13}$ menggunakan klaritromisin saja yang melaporkan tidak memberikan perbaikan fungsi penghidu pada rinosinusitis kronik.

Terdapat perbaikan skor nasoendoskopi yang sangat bermakna pra dan pascaterapi pada kedua kelompok yang meliputi perbaikan edema mukosa dan sekret hidung, namun secara statistik melalui Uji Mann Whitney tidak didapatkan perbedaan yang bermakna antara kedua kelompok. Cervin dkk. ${ }^{15}$ mendapatkan 12 dari 17 pasien rinosinusitis berespons baik dengan pengobatan klaritromisin 1x250 mg, secara statistik terdapat perbaikan skor nasoendoskopi dan VAS yang meliputi obstruksi hidung dan rinore. Skor nasoendoskopi dapat menggambarkan derajat berat inflamasi mukosa. Riffer dkk. ${ }^{16}$ menyatakan pemberian klaritromisin lebih baik bila dibandingkan dengan amoksisilinklavulanat dalam hal menurunkan produksi sekret purulen nasal, namun pada penelitian ini pada kedua kelompok sama-sama memiliki efektivitas yang baik dalam memperbaiki skor sekret pra dan pascaterapi. Hal ini menunjukkan bahwa kedua antibiotik memiliki daya eradikasi yang baik terhadap bakteri patogen sinus dan membuktikan bahwa bakteri patogen masih sensitif terhadap kedua jenis antibiotik tersebut.

Terlihat perbedaan skor ADI yang sangat bermakna pada pra dan pascaterapi dengan Uji Wilcoxon dengan nilai $\mathrm{p}=0,003$ pada kedua kelompok penelitian ini. Terlihat kecenderungan peningkatan skor ADI yang lebih baik pada perlakuan bila dibandingkan dengan kontrol, namun berdasarkan Uji Mann Whitney tidak didapatkan perbedaan bermakna antara kedua kelompok. Gaines ${ }^{5}$ dalam artikelnya menyatakan bahwa inflamasi merupakan faktor yang utama menyebabkan gangguan fungsi penghidu di samping faktor-faktor lainnya seperti kerusakan mukosa dan sensorineural. Faktor inflamasi ini menyebabkan edema mukosa yang kemudian menyebabkan obstruksi nasal, sehingga odoran tidak dapat mencapai epitel olfaktori dan terjadi gangguan fungsi penghidu. Perbaikan fungsi penghidu praterapi dan pascaterapi pada kedua kelompok berkaitan erat dengan peranan agen antiinflamasi (kortikosteroid topikal intranasal) yang dipergunakan pada kedua kelompok untuk menekan proses inflamasi. Hal ini menyebabkan gangguan fungsi penghidu secara konduktif dan peranan klaritromisin yang dapat secara sinergis dengan kortikosteroid intranasal yang bekerja saling memperkuat efektivitas perbaikan fungsi penghidu, meskipun antara kelompok perlakuan dan kontrol tidak berbeda bermakna, tetapi pada kelompok perlakuan fungsi penghidu cenderung lebih baik dibandingkan dengan kontrol.

Terdapat penurunan yang bermakna kadar IL-8 kedua kelompok pra dan pascaterapi, namun dengan Uji Mann Whitney memberikan hasil yang tidak bermakna karena sama efektifnya menurunkan kadar IL-8. Hal ini terjadi karena glukokortikoid mampu menghambat produksi IL-8 dan MCP-1 yang dihasilkan oleh eosinofil dan neutrofil. Mekanisme kerja glukokortikoid adalah kemampuan untuk melakukan penetrasi ke dalam sel-sel dan kemudian berikatan dengan reseptor glukokortikoid (GR). Kompleks GR ini dapat secara langsung berinteraksi dengan faktor transkripsi seperti NF-kB dan AP-1. Hal ini diyakini merupakan mekanisme mayor efek antiinflamasi kortikosteroid. ${ }^{17}$ Kikuchi dkk. ${ }^{10}$ meneliti secara in vitro dan menemukan bahwa klaritromisin bekerja pada monosit dan sel epitel hidung serta dapat menekan sinyal LPS bakteri yang pada akhirnya dapat menghambat AP-1 dan NF-kB. Hal ini menujukkan bahwa klaritromisin efektif menekan produksi IL-8 pada lokasi tempat infeksi. Menurut Mac-Leod dkk. ${ }^{18}$ terapi klaritromisin $2 \times 500 \mathrm{mg}$ secara bermakna menurunkan kadar IL-8, efek ini selaras dengan perbaikan pada skor edema pra dan pascaterapi dan perbaikan gejala klinis yang meliputi nyeri sinus, nyeri kepala, obstruksi hidung, dan rinore setelah 14 hari terapi. Klaritromisin telah dibuktikan dapat meningkatkan sensitivitas reseptor steroid, 
sehingga dapat meningkatkan efek terapi glukokortikoid. ${ }^{8}$ Hal ini menjadi bukti kuat bahwa antara klaritromisin dan kortikosteroid mampu bersinergi dalam menurunkan inflamasi. Pada penelitian ini kombinasi klaritromisin dengan kortikosteroid topikal menunjukkan penurunan persentase rata-rata yang lebih baik dibandingkan dengan kelompok kontrol meskipun secara uji statistik sama baiknya dengan kelompok kontrol.

Berdasarkan hasil ini muncul dugaan bahwa amoksisilin-klavulanat juga mempunyai efek antiinflamasi, walaupun belum banyak data penelitian mengenai efek antiinflamasi yang dimiliki oleh amoksisilin-klavulanat. Penelitian yang dilakukan oleh Casellas dkk. ${ }^{19}$ menemukan bukti bahwa amoksisilin-klavulanat dosis besar untuk terapi kolitis ulseratif memperlihatkan efek antiinflamasi yang ditandai dengan penurunan marker inflamasi IL-8 dan eicosanoids intraluminal, namun dalam penelitiannya tidak dapat dijelaskan melalui mekanisme apa amoksisilinklavulanat mampu menurunkan inflamasi.

Terlihat korelasi yang bermakna penurunan kadar IL-8 sekret mukosa hidung dengan VAS hidung tersumbat pada kelompok perlakuan dengan Uji Korelasi Rank Spearman $(\mathrm{p}=0,02)$. Hal ini menunjukkan keterkaitan faktor inflamasi yang menyebabkan obstruksi nasal dengan kadar IL-8 sekret hidung pada rinosinusitis kronik tanpa polip nonalergi. Dapat juga dilihat korelasi antara IL-8 dan skor penghidu (ADI) jika dilakukan uji satu pihak dengan nilai $\mathrm{p}=0,05$ (nilai $\mathrm{p}$ uji 2 pihak dibagi 2). Hal ini menunjukkan bahwa gangguan fungsi penghidu yang terjadi pada pasien rinosinusitis memiliki dasar inflamasi yang menimbulkan obstruksi nasal sehingga terjadi gangguan konduksi odoran. Faktor inflamasi ini yang diketahui memiliki keterkaitan dengan kadar IL-8 sekret hidung. Dengan temuan korelasi ini, maka kadar IL-8 sekret mukosa hidung dapat dijadikan parameter beratnya penyakit khususnya keluhan hidung tersumbat dan gangguan fungsi penciuman. Dalam penelitiannya Jordan dkk. ${ }^{20}$ menemukan korelasi bermakna antara mediator inflamasi (IL-5, IL-8, MCP-1, eotaxin, sVCAM-1, dan LTC-4) dengan keluhan hidung tersumbat.

Simpulan, klaritromisin yang dikombinasikan kortikosteroid intranasal efektif memperbaiki gejala klinis terutama keluhan hidung tersumbat, meningkatkan fungsi penghidu, dan menurunkan kadar IL-8 sekret mukosa hidung pada RSK tanpa polip nonalergi. Klaritromisin dapat dijadikan pilihan terapi medikamentosa yang optimal pada RSK tanpa polip-nonalergi dengan frekuensi minum obat per hari lebih sedikit yakni 2 kali per hari sehingga lebih meningkatkan kepatuhan minum obat bagi pasien dibandingkan dengan amoksisilin-klavulanat 3 kali per hari.

\section{Daftar Pustaka}

1. Fokkens WJ, Lund VJ, Mullol J, Bachert C, Alobid I, Baroody F, dkk. EPOS 2012: European position paper on rhinosinusitis and nasal polyps 2012. A summary for otorhinolaryngologists. Rhinology. 2012; 50(1):1-12.

2. Prastianingsih $P, \quad$ Madiadipoera $T$, Lasminingrum L. Perbandingan jumlah eosinofil dan kadar IL-5 pada mukosa hidung antara rinosinusitis kronis disertai polip hidung dengan yang tanpa polip hidung [tesis]. Bandung: Universitas Padjadjaran; 2006.

3. Brandsted R, Sindwani R. Impact of depression on disease-specific symptoms and quality of life in patients with chronic rhinosinusitis. Am J Rhinol. 2007;21(1):504.

4. Kennedy DW. Pathogenesis of chronic rhinosinusitis. Ann Otol Rhinol Laryngol. 2004;193(Suppl):6-9.

5. Gaines AD. Anosmia and hyposmia. Allergy Asthma Proc. 2010;31(3):185-9.

6. Yee KK, Pribitkin EA, Cowart BJ, Vainius AA, Klock CT, Rosen D, dkk. Neuropathology of the olfactory mucosa in chronic rhinosinusitis. Am J Rhinol Allergy. 2010;24(2):110-20.

7. Wallwork B, Coman W, Feron F, MackaySim A, Cervin A. Clarithromycin and prednisolone inhibit cytokine production in chronic rhinosinusitis. Laryngoscope. 2002;112(10):1827-30.

8. Scadding GK. Medical management of chronic rhinosinusitis. Immunol Allergy Clin North Am. 2004;24(1):103-18.

9. Ariza H, Rojas R, Johnson P, Gower R, Benson A, Herrington J, dkk. Eradication of common pathogens at days 2, 3 and 4 of moxifloxacin therapy in patients with acute bacterial sinusitis. BMC Ear Nose Throat Disord. 2006;6:8.

10. Kikuchi T, Hagiwara K, Honda Y, Gomi K, Kobayashi T, Takahashi $\mathrm{H}$, dkk. Clarithromicyn suppresses lipopolysaccharide-induced interleukin-8 production by human monocytes through AP-1 and NF-kappa B transcription factors. Antimicrobial Chemother. 2002; 49(5):745-55.

11. Rechtweg JS, Moinuddin R, Houser SM, Mamikoglu B, Corey JP. Quality of life in treatment of acute rhinosinusitis with clarithromycin and amoxicillin/clavulanate. Laryngoscope. 2004;114(5):806-10.

12. Pilan RR, Pinna FR, Bezerra TF, Mori 
RL, Padua FG, Bento RF, dkk. Prevalence of chronic rhinosinusitis in São Paulo. Rhinology. 2012;50(2):129-38.

13. Sarafraz M, KhosraviAD, Ahmadi K. Clinical and microbiological evaluation of long term clarithromycin in the treatment of chronic rhinosinusitis. J Med Sci. 2008;8(7):669-72.

14. Moretti A, Augurio A, Croce A. Antiinflamatory and anti-allergy drugs in rhinosinusitis. Antiinflamm Antiallergy Agents Med Chem. 2009;8(1):101-13.

15. Cervin A, Wallwork B, Mackay-Sim A, Coman WB, Greiff L. Effects of longterm clarithromycin treatment on lavagefluid markers of inflammation in chronic rhinosinusitis. Clin Physiol Funct Imaging. 2009;29(2):136-42.

16. Riffer E, Spiller J, Palmer R, Shortridge $\mathrm{V}$, Busman TA, Valdes J. Once daily clarithromycin extended-release vs twicedaily amoxicillin/clavulanate in patients with acute bacterial sinusitis: a randomized, investigator-blinded study. Curr Med Res Opin. 2005:21(1):61-70.

17. Janka-Junttila M, Moilanen E, Hasala $H$, Zhang X, Adcock I, Kankaanranta H. The glucocorticoid RU24858 does not distinguish between transrepression and transactivation in primary human eosinophils. J Inflam. 2006;3:1-10

18. Mac-Leod CM, Hamid QA, Cameron L, Tremblay C, Brisco W. Antiinflammatory activity of clarithromycin in adults with chronically inflamed sinus mucosa. Adv Ther. 2001;18(2):75-82.

19. Casellas F, Borruel N, Papo M, Guarner F, Antolín M, Videla S, dkk. Antiinflammatory effects of enterically coated amoxicillinclavulanic acid in active ulcerative colitis. Inflamm Bowel Dis. 1998;4(1):1-5.

20. Jordan TR, Pfrogner E, Rasp G, Kramer MF. Clinical symptoms and mediators in the allergic early and late phase reaction. Laryngorhinootologie. 2006;85(2):113-23. 